Creative commons User License: CC BY-NC-ND

Abstracted by: EBSCOhost, Electronic Journals Service (EJS),

Google Scholar, Directory of Open Access Journals (DOAJ),

Journal Seek, Scientific Commons,

Food and Agricultural Organization (FAO), CABI and Scopus
Journal of Agricultural Extension

Vol. 21 (2) June, 2017

ISSN(e): 24086851; ISSN(Print); 1119944X

http://journal.aesonnigeria.org

http://www.ajol.info/index.php/jae

Email: editorinchief@aesonnigeria.org

\title{
Effects of National Fadama III Programme on the Scope and Scale of Beneficiaries' Farming Activities in South West, Nigeria
}

https://dx.doi.org/10.4314/jae.v21i2.7

\section{Agunloye, T.O.}

Department of Agricultural Extension and Communication Technology

Federal University of Technology, Akure, Nigeria

Email: timo4diamond@yahoo.com ; Phone: 08039485617

Fasina, 0.0.

Department of Agricultural Extension and Communication Technology

Federal University of Technology, Akure, Nigeria

Email: royalambfuta@gmail.com ; Phone: 08066649331

\author{
Akinnagbe, O.M. \\ Department of Agricultural Extension and Communication Technology \\ Federal University of Technology, Akure, Nigeria \\ Email: omakinnagbe@futa.edu.ng; Phone: 08035399151
}

\section{Abstract}

This paper examined the effects of National Fadama III programme on the scale and scope of beneficiaries farming activities in the study area.. Two hundred randomly selected beneficiaries were used. Data were collected with the aid of structured interview schedule and analyzed using frequency, percentage and mean statistics. Results revealed that beneficiaries' scope of crop production increased significantly for maize, cassava, yam, plantain and agro processing. The scope of livestock production also increased for goatry, fisheries, poultry and for fish processing and a sharp decrease for piggery. The scale of crop production also revealed an increase significantly for cassava production, maize, yam and plantain. For livestock production, the mean population rose for poultry, goatry, fisheries and piggery. The income of beneficiaries also rose by 58\%. The study recommended that the federal government should sustain the Fadama programme after World Bank withdraws from funding the programme.

Keywords: Fadama III, beneficiaries, Farm Scale and Scope,

\section{Introduction}

Agriculture is the backbone of Nigeria's economy, despite being a leading producer of oil in the African region. Agriculture generated 30.9 percent growth in the economy outside the oil sector in 2015 (NBS, 2015). However excessive real exchange rate appreciation and overvaluation following the oil booms, along with distortions induced by an import substitution industrialization policy, reduced agricultural competitiveness and investment (Ekpo and Umoh, 2012). 
Creative commons User License: CC BY-NC-ND

Abstracted by: EBSCOhost, Electronic Journals Service (EJS),

Google Scholar, Directory of Open Access Journals (DOAJ),

Journal Seek, Scientific Commons,

Food and Agricultural Organization (FAO), CABI and Scopus
Journal of Agricultural Extension

Vol. 21 (2) June, 2017

ISSN(e): 24086851; ISSN(Print); 1119944X

http://journal.aesonnigeria.org

http://www.ajol.info/index.php/jae

Email: editorinchief@aesonnigeria.org

In response, the federal government of Nigeria evolved and implemented several agricultural programmes. According to Oriola (2009), these programmes were designed to revolutionize the agricultural sector which was derailing from its normal contribution to the economy. However, while many of these programmes have gone moribund, some were short lived, and others have made remarkable impact, though not without challenges or limitations. The National Fadama Development Programmes (NFDP) came on board as a result of the success recorded by the small scale irrigation projects carried out by the Agricultural Development Programmes (ADPs) in fadama areas.

"Fadama" is a Hausa word which translates to Irrigable land in English Language and it means "akuro" in Yoruba language. Fadama can be described as a local word for low lying flood plain usually with easily accessible shallow groundwater (Balogun et. al, 2011). It is especially suitable for crop irrigation and fishing which traditionally provides food and water for livelihood. However, the operationalization of the word "Fadama" in the context of World Bank assisted project (especially Fadama III) is more like an agricultural diversification programme.

The first National Fadama Development Project (NFDP-1) was established in the 1990s to promote simple low cost improved irrigation technology under the World Bank financing. The main objective of NFDP-1 was to sustainably increase the incomes of the Fadama users through expansion of farm and non-farm activities with high value-added output. The programme covered twelve's states of Adamawa, Bauchi, Gombe, Imo, Kaduna, Kebbi, Lagos, Niger, Ogun, Oyo, Taraba including the Federal Capital Territory (FCT). NFDP adopted community driven development (CDD) approach with extensive participation of stakeholders at the early stage of the project. This approach is in line with policies and development strategies for Nigeria with emphasis on poverty reduction, private sector leadership and beneficiary participation. Overall appraisal of the first phase of the project showed remarkable success (Akinola, 2003).

The success recorded in Fadama I led to the establishment of Fadama II. The strategy for Fadama II was aimed at contributing to food security and increased access to rural infrastructure facilities. Consequently, Fadama II programme was assisted by World Bank and co -financed with loan from African Development Fund (ADF). Fadama II was more of agricultural diversification programmes providing financing for the diverse livelihood activities which the beneficiaries themselves identify and design, with appropriate facilitation support. Fadama II was implemented in 12 States including the Federal Capital territory, Abuja. The 12 Fadama II states were carried out in three major agro- ecological Zones. The humid forest (Lagos, Ogun and Imo), moist savannah (Adamawa, FCT, OYO and Taraba) and dry savannah (Bauchi, Gombe, Kaduna, Kebbi and Niger).

Fadama III Project was a comprehensive five-year action programme developed by the Federal Ministry of Agriculture and Water Resources (FMAWR) in close collaboration with the Federal Ministry of Environment (FME) and other Federal and State government ministries, local governments and key stakeholders (donors, private operators, NGOs). The first Fadama project (Fadama I) focused exclusively on irrigation farming while both Fadama II and Fadama III are more of agricultural 
Creative commons User License: CC BY-NC-ND

Abstracted by: EBSCOhost, Electronic Journals Service (EJS),

Google Scholar, Directory of Open Access Journals (DOAJ),

Journal Seek, Scientific Commons,

Food and Agricultural Organization (FAO), CABI and Scopus
Journal of Agricultural Extension

Vol. 21 (2) June, 2017

ISSN(e): 24086851; ISSN(Print); 1119944X

http://journal.aesonnigeria.org

http://www.ajol.info/index.php/jae

Email: editorinchief@aesonnigeria.org

diversification programmes, providing financing for the diverse livelihood activities which the beneficiaries themselves identify and design, with appropriate facilitation support.

The main objective of the Fadama III Project was to increase the income of users of rural land and water resources on a sustainable basis. By increasing their incomes, the project helped reduce rural poverty, increase food security, and contribute to the achievement of the Millennium Development Goal (MDG). The specific objectives were to;

1 sustainably increase the incomes of Fadama beneficiaries by directly delivering resources to them (i.e. the beneficiary rural communities), efficiently and effectively;

2 Empower beneficiaries to collectively decide on how resources are allocated and managed for their livelihood activities and to participate in the design and execution of their sub-projects.

The key indicators and targets for tracking progress toward the project development objective of Fadama III were:

1. Income of participating households: 75 percent of Fadama user households, who benefit directly from project-supported activities, would have increased their average real incomes by at least 40 percent by 2013.

2. Yields of primary agricultural products of participating households: 20 percent increase in yield of primary agricultural products of participating households.

3. Savings of participating groups: 10 percent of the replacement value of the common asset used for income-generating activities of the FUGs is saved annually (with effect from year 2).

4. Physical verification of operations, maintenance and utilization of assets at midterm and at project closing by surveys of random selected sites

The Fadama project utilizes the Community Driven Development (CDD) approach and has placed beneficiaries in the driver's seat. Local community members, under the umbrella of Fadama Community Associations (FCAs) and Fadama User Groups (FUGs), oversee the design and implementation of the project and are empowered through skills and capacity-building to improve their livelihoods by increasing income generating activities.

The Fadama III programme was concluded in the year 2013 and it is necessary to find out how the programme has impacted on the livelihood of beneficiaries especially the scope and scale of their farming activities. Increase the scope (number of farm production activities) involved before Fadama III the scale (change in production capacity) due to Fadama III programme.

\section{Objectives of the study}

The main objective was to determine the changes in scope and scale of farmers due to the National Fadama Development Project III in South West, Nigeria. Specifically, the study sought to ascertain if the farm activities of beneficiaries has increased in scope and scale after the programme. 
Creative commons User License: CC BY-NC-ND

Abstracted by: EBSCOhost, Electronic Journals Service (EJS),

Google Scholar, Directory of Open Access Journals (DOAJ),

Journal Seek, Scientific Commons,

Food and Agricultural Organization (FAO), CABI and Scopus
Journal of Agricultural Extension

Vol. 21 (2) June, 2017

ISSN(e): 24086851; ISSN(Print); 1119944X

http://journal.aesonnigeria.org

http://www.ajol.info/index.php/jae

Email: editorinchief@aesonnigeria.org

\section{Methodology}

The study was conducted in Ondo and Osun States, Nigeria. A Multistage sampling technique was used in selection of respondents for the study. Stage one involved selection of 20 percent of the Local Government Areas (LGAs) out of the 30 and 18 LGAs in Osun and Ondo states, respectively yielding six (6) LGAs in Osun and four (4) LGAs in Ondo State. The second stage involved a random selection of two 2 Fadama Community Associations (FCAs) from each LGA making a total of twenty (20) FCAs, 12 FCAs from Osun and 8 FCAs from Ondo. The third stage involved a purposive selection of two 2 Fadama User's Group (FUG's) (1 crop and 1 livestock) from each of the FCAs. This gave 24 FUG's from Osun and 16 from Ondo making a total of 40 . The fourth stage involved a random selection of five beneficiary farmers from each the FUG's producing 120 in Osun and 80 in Ondo making a total of 200. Primary data were collected through the use of interview schedule.

Scope was operationalized as the number of farm activities the farmers were involved in before and after Fadama III programme while the scale was operationalized as the farm size of the farmers before and after the programme.

To ascertain whether the activities of the beneficiaries increased in scope and scale; the beneficiaries were asked to state farming activities before and after benefiting from Fadama III programme. Frequency, percentage and mean statistic were used to analyze the data.

\section{Results and Discussion}

\section{Socio-Economic Characteristics of the Respondents}

The majority $(64 \%)$ of the respondents were male and married (83.5\%) (Table 1$)$. The mean age of the farmers was 47years, implying that the participants were in their active age which could likely be a prospect for greater productivity and higher input. The mean household size of the respondents was six persons. 
Creative commons User License: CC BY-NC-ND

Abstracted by: EBSCOhost, Electronic Journals Service (EJS),

Google Scholar, Directory of Open Access Journals (DOAJ),

Journal Seek, Scientific Commons,

Food and Agricultural Organization (FAO), CABI and Scopus
Journal of Agricultural Extension

Vol. 21 (2) June, 2017

ISSN(e): 24086851; ISSN(Print); 1119944X

http://journal.aesonnigeria.org

http://www.ajol.info/index.php/jae

Email: editorinchief@aesonnigeria.org

Table 1: Distribution of respondent' according to their socioeconomic characteristics

\begin{tabular}{lll}
\hline Variable & Percentage & Mean \\
\hline Sex & & \\
Male & 64.0 & \\
Female & 36.0 & \\
Marital Status & 6.5 \\
Single & 83.5 \\
Married & 1.5 & \\
Separated & 3.0 & \\
Divorced & 5.5 & \\
Widowed & & \\
Age (years) & & \\
$\leq 30$ & 5.0 & \\
$31-35$ & 7.5 & \\
$36-40$ & 17.5 & \\
$41-60$ & 17.0 & \\
$46-50$ & 16.5 & \\
$51-55$ & 16.5 & \\
$56-60$ & 11.5 & \\
$\geq 61$ & 8.5 & \\
Households & & \\
size & & \\
$1-3$ & 11.0 & \\
$4-6$ & 59.5 & \\
$7-9$ & 25.5 & \\
$\geq 10$ & 4.0 & \\
\end{tabular}

\section{Effects of Fadama III on the Scope and Scale of Farmers farming Activities Scope of Arable Crop Farming Activities}

Figure 1 reveals an increase in the number of farmers growing specific crops before and after the intervention. The number of farmers that planted maize increased from $25 \%$ to $28 \%$ after the programme. The number of farmers involved in cassava production also increased from $50 \%$ before to $68 \%$ after. The number of beneficiaries that planted yam increased from $18 \%$ before the programme to $22 \%$ after the programme. Also, the number of people that planted plantain increased from $10 \%$ before Fadama programme to $16 \%$ after the programme. This is in support of Koyenikan and Ikharea (2014) findings that fadama users group (fadama beneficiaries) were highly involved in arable crop enterprises such as cassava and plantain in Edo State, Nigeria.

The results of the study also revealed that the number of agro-processors increased from $16 \%$ to $53 \%$ after the programme. It is also interesting to note that cassava production has the highest number of beneficiaries involved in it so also the agro processing. The awareness on the need for agro processing is now increasing 
Creative commons User License: CC BY-NC-ND

Abstracted by: EBSCOhost, Electronic Journals Service (EJS), Google Scholar, Directory of Open Access Journals (DOAJ), Journal Seek, Scientific Commons,

Food and Agricultural Organization (FAO), CABI and Scopus

\section{Journal of Agricultural Extension}

Vol. 21 (2) June, 2017

ISSN(e): 24086851; ISSN(Print); 1119944X

http://journal.aesonnigeria.org

http://www.ajol.info/index.php/jae

Email: editorinchief@aesonnigeria.org

because of the need for value addition. Generally, there were increased in the proportion of farmers involved in planting different crops, therefore the scope of farming activities had increased. This could be attributed to the various supports (grant, capacity building) provided by the programme.

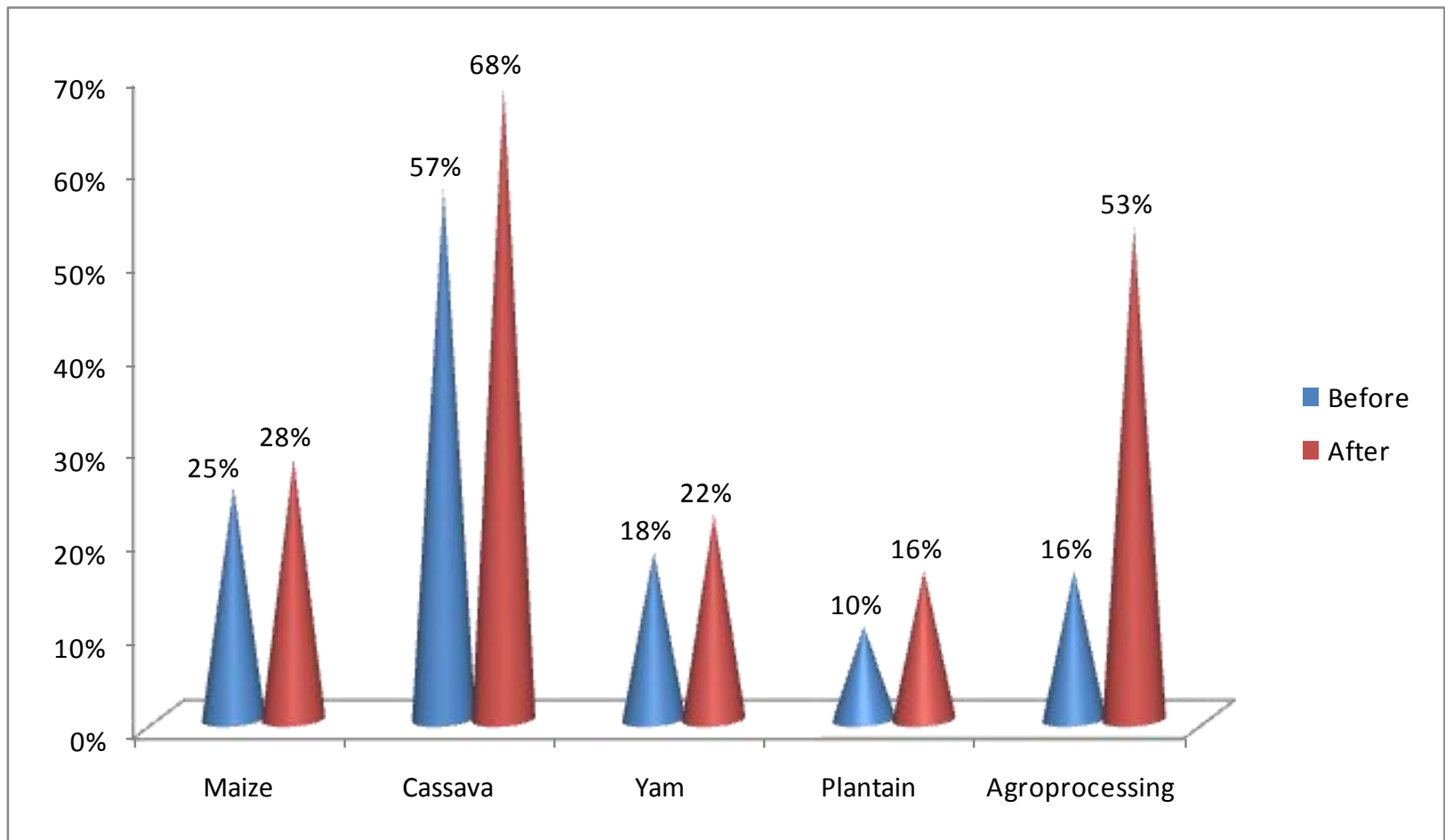

Figure 1: Scope of the crop production activities before and after Fadama III programme implementation

Source: Field Survey, 2015

\section{Scope of Livestock Farming Activities}

Results in Figure 2 showed an increase in the number of farmers involved in livestock farming before and after involved in Fadama programme. There was an increase for goat farming (before $=3.0 \%$, after $=10.0 \%$ ), piggery (before $=11.0 \%$, after $=8.0 \%$ ), fisheries (before $=13.0 \%$, after $=31.0 \%$ ), poultry (before $=10.0 \%$, after $=38.0 \%$ ) and fish processing (before $=4.0 \%$, after $=11.0 \%$ ). The results revealed that the number of farmers that were involved in goat rearing, fisheries, poultry and fish processing increased in number. It is also evident from the result that the percentage increase in the number of farmers involved in poultry farming were more than other enterprises. Reasons adduced was as a result of the demand for white meat. Poultry keeping has gain popularity in developing countries because of the low capital start up.

It is also interesting to note that the numbers of farmers involved in piggery production were reduced after the Fadama programme. The reduction in the percentage of people that participated in piggery after Fadama III could be as result of religious sentiments. It could also be that some of the respondents diversified to other farm enterprise like fish processing or agro processing which presumably could 
Creative commons User License: CC BY-NC-ND

Abstracted by: EBSCOhost, Electronic Journals Service (EJS),

Google Scholar, Directory of Open Access Journals (DOAJ),

Journal Seek, Scientific Commons,

Food and Agricultural Organization (FAO), CABI and Scopus
Journal of Agricultural Extension

Vol. 21 (2) June, 2017

ISSN(e): 24086851; ISSN(Print); 1119944X

http://journal.aesonnigeria.org

http://www.ajol.info/index.php/jae

Email: editorinchief@aesonnigeria.org

yield more money to their household. This contradicts the findings of Girei, et.al., 2017 on the level of involvement of Fadama beneficiaries in Plateau State. In their finding, Fadama beneficiaries were moderately involved in Livestock enterprises like piggery and poultry.

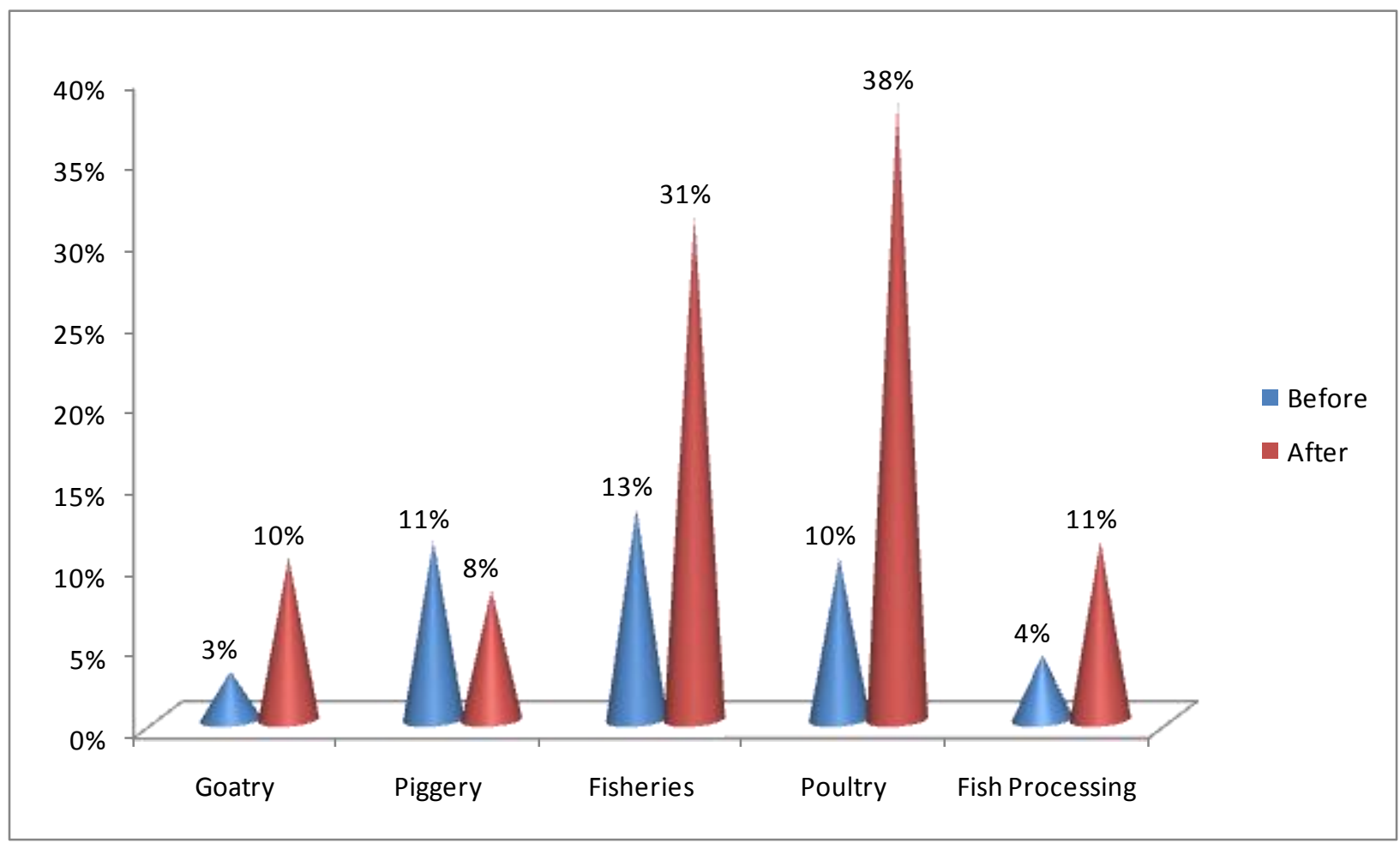

\section{Figure 2: Scope of the Livestock production activities before and after Fadama III programme implementation}

Source: Field Survey, 2015

\section{Scale of Arable Crop Farming Activities}

Figure 3 shows the scale of respondent's crop farming activities in cassava, maize, yam, and plantain farm sizes before and after Fadama programme. The number of famers that increased their farm size for cassava production before participating in Fadama programme was $12.5 \%$ after involved in Fadama programme, the percentage of farmers that increased their farm size for cassava production were $16.7 \%$. The proportion of farmers that increased their farm size for maize production before participating in Fadama programme was 13.0\% while $17.6 \%$ increased their farm size for maize production after participating in Fadama programme. Also, $10.0 \%$ of the respondents increased the farm size for yam production before participating in Fadama programme, while 10.6\% increase their farm size for yam production after participating in Fadama programme. Only about $8 \%$ of the respondents increased their farm size for plantain production before participating in Fadama programme but after participating in Fadama programme, the proportion that increased their farm size rose to about $10 \%$. 
Creative commons User License: CC BY-NC-ND

Abstracted by: EBSCOhost, Electronic Journals Service (EJS), Google Scholar, Directory of Open Access Journals (DOAJ), Journal Seek, Scientific Commons,

Food and Agricultural Organization (FAO), CABI and Scopus

\author{
Journal of Agricultural Extension \\ Vol. 21 (2) June, 2017 \\ ISSN(e): 24086851; ISSN(Print); 1119944X \\ http://journal.aesonnigeria.org \\ http://www.ajol.info/index.php/jae \\ Email: editorinchief@aesonnigeria.org
}

The result further revealed that, though there was an increase in the number of participating farmers that increased their farm sizes for all the crop planted. There was a higher increase in the number of those that increased their farm size for cassava and maize production. Cassava and Maize were regarded as the major staple food for Nigerian, hence the increase in the number of people that increased their farm sizes for these crops. The increase in the number of people could also results to higher output of cassava and maize products which could help in reducing hunger.

The increase in the farm sizes after Fadama III programme could also be as a result of incentives in form of inputs supports, matching fund grants, trainings and capacity building made available to the farmers during the programme implementation. Also the high output recorded by the respondents after the programme especially in cassava and maize production could also be as a result that Fadama farmers have embraced the new policies and programmes of agriculture in Nigeria which is centered on harnessing value chain of agricultural products especially cassava and maize and increase household income.

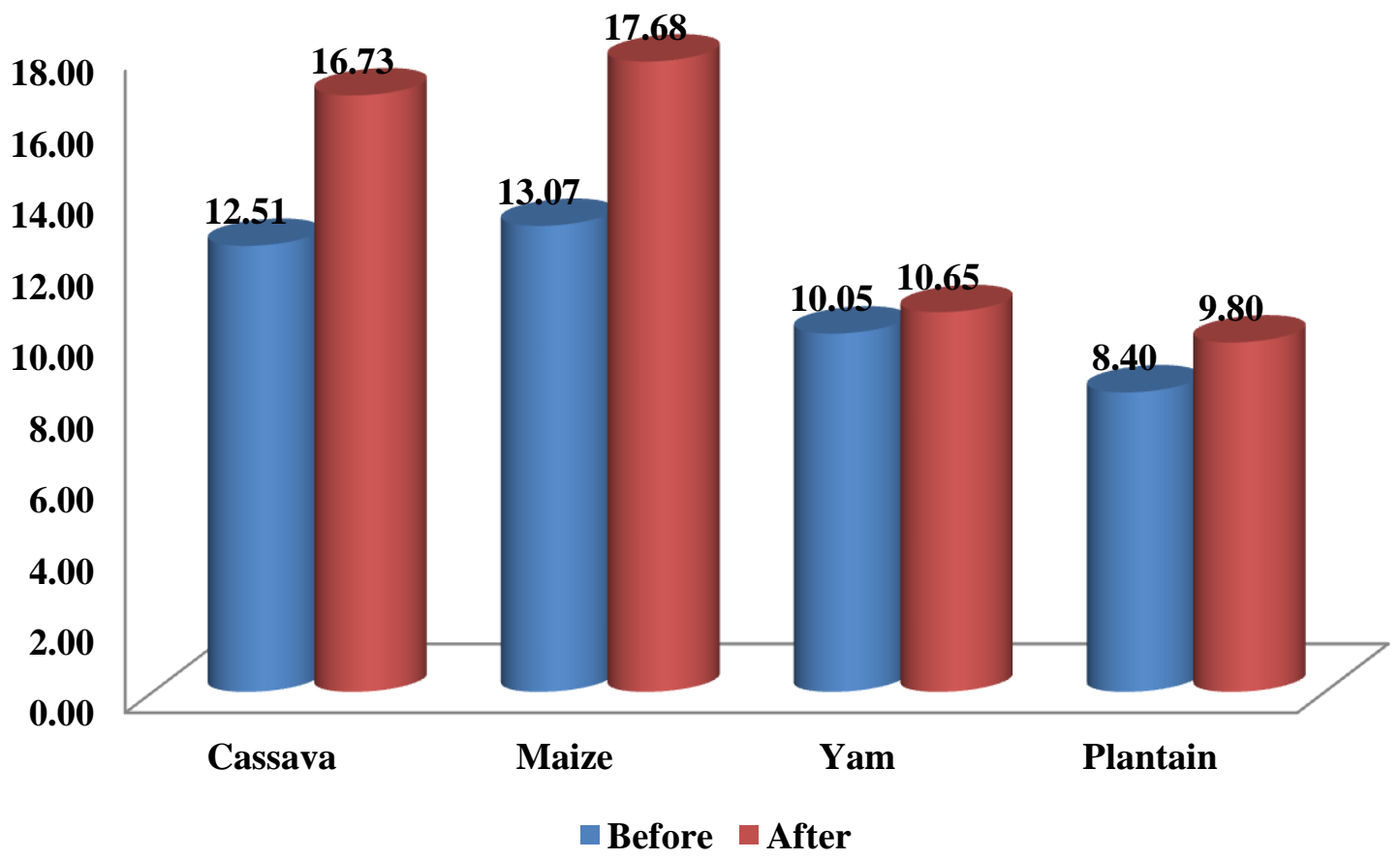

Figure 3: Scale of farm size before and after Fadama III programme implementation Source: Field Survey, 2015

\section{Average farm size}

Results in figure 4 showed the scale of respondent's average farm size of Cassava, Maize, Yam, and Plantain in hectares before and after Fadama programme. The average farm size for cassava before participating in Fadama programme was 1.04 hectares while after participating in Fadama programme, the farm size for cassava production increased to 1.45 hectares, indicating an increase of 0.41 hectares. The average farm size for maize production before Fadama programme was 1.03 
Creative commons User License: CC BY-NC-ND

Abstracted by: EBSCOhost, Electronic Journals Service (EJS),

Google Scholar, Directory of Open Access Journals (DOAJ),

Journal Seek, Scientific Commons,

Food and Agricultural Organization (FAO), CABI and Scopus
Journal of Agricultural Extension

Vol. 21 (2) June, 2017

ISSN(e): 24086851; ISSN(Print); 1119944X

http://journal.aesonnigeria.org

http://www.ajol.info/index.php/jae

Email: editorinchief@aesonnigeria.org

hectares, while after Fadama programme, it was 1.55 hectares, indicating an increase in farm size of 0.52 hectares. The average farm size for yam production before Fadama was 0.75 hectares, while after the programme it increases to 1.16 hectares, with a difference of 0.41 hectares. The average farm size for plantain production before Fadama production was 0.74 hectares while after the programme it was 0.86 hectares, showing an increase of 0.12 hectares.

This result is in agreement with the findings of Ogbonna and Nwaobiala, (2014), which showed the mean size of farmland cultivated by fadama women farmers in Gombe state increased to 2.62 hectare as compared to non-participating farmers with the mean farm size of 2.39 hectares. This finding is also in collaboration with the results of Osondu et al., (2015), where the mean farm size of Fadama III farmers was higher than that of the non-Fadama III farmers with a mean difference of 0.56 hectare.

This implies that there was an increase in the farm size of cassava, maize, yam and plantain farmers respectively after participation in Fadama III programme which indicates that Fadama III had positive effects on the scale of production in crop activities. The increase in the farm size recorded by the respondents after the programme could be as a result that Fadama farmers have embraced farming as business whereby they can make more money and earn a good living.

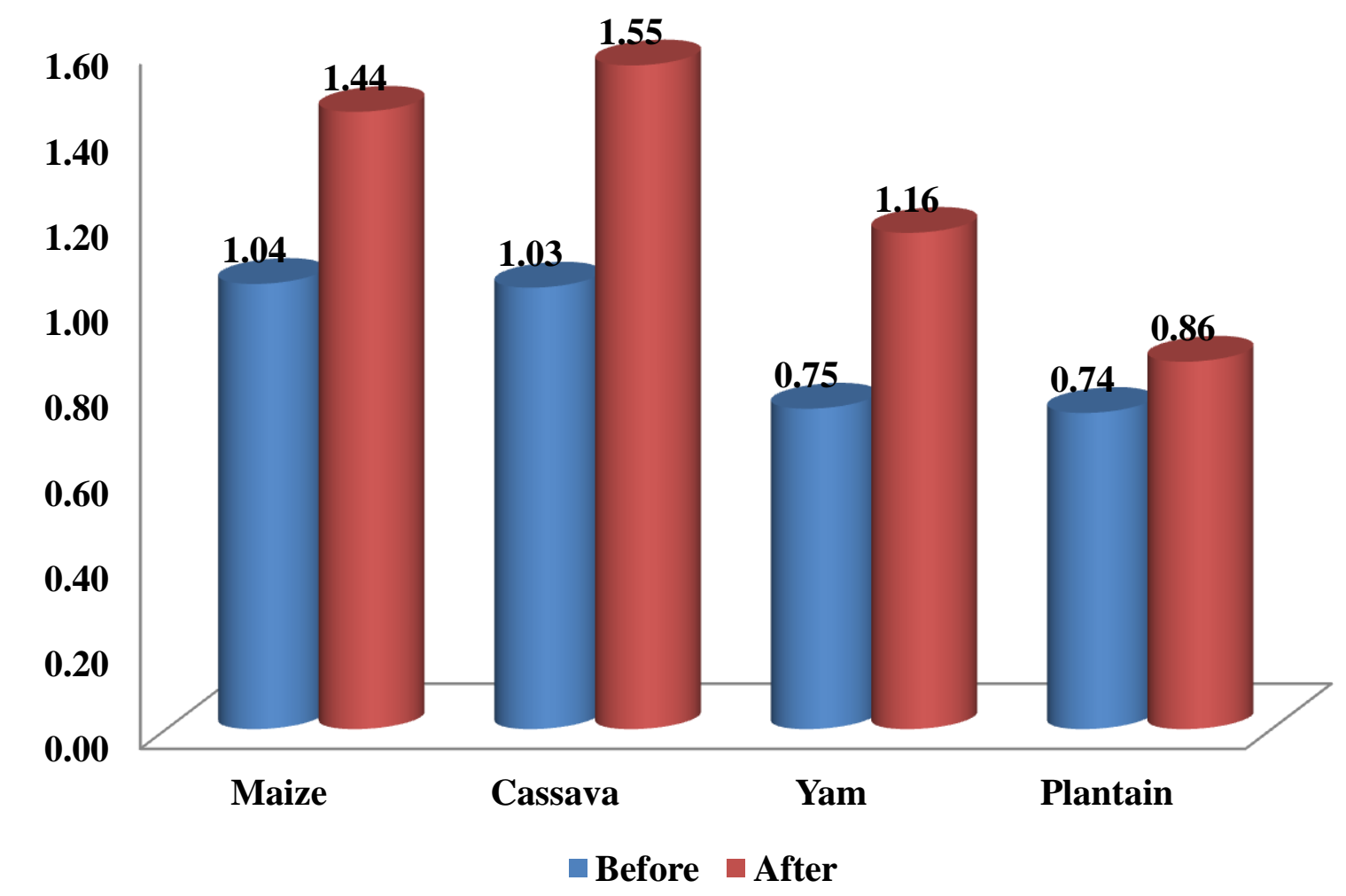

Figure 4: Farm size of crop production before and after Fadama III programme Source: Field Survey, 2015 
Creative commons User License: CC BY-NC-ND

Abstracted by: EBSCOhost, Electronic Journals Service (EJS), Google Scholar, Directory of Open Access Journals (DOAJ), Journal Seek, Scientific Commons,

Food and Agricultural Organization (FAO), CABI and Scopus
Journal of Agricultural Extension

Vol. 21 (2) June, 2017

ISSN(e): 24086851; ISSN(Print); 1119944X

http://journal.aesonnigeria.org

http://www.ajol.info/index.php/jae

Email: editorinchief@aesonnigeria.org

\section{Scale of Livestock Farming Activities}

Figure 5 shows the scale of respondent's Livestock farming activities such as poultry, goatry, piggery and fisheries before and after Fadama programme. The average number of poultry birds produced by the respondents before Fadama programme was 76 birds, while after the programme 202 poultry birds were kept. The average number of goat kept by the farmers before the programme was 16 , after the programme, average of 46 goats were kept. The average number of Fishes kept before Fadama programme was 410, after the programme it was 816 in number. The number of Pigs before was 28, after it was 64. It is interesting to note that though the number of farmers involved in piggery reduced from $11.0 \%$ before Fadama programme to $8.0 \%$ after Fadama programme as indicated in figure 2, the quantity produced increased from 28 to 64 as indicated in Figure 5.

Keeping livestock is an important risk reduction strategy for vulnerable communities, and livestock are important providers of nutrients and traction for growing crops in smallholder systems. Livestock products contribute 17 per cent to kilocalorie consumption and 33 per cent to protein consumption globally, but there are large differences between rich and poor countries (Rosegrant et al, 2009) This implies that, the proportion of those that increased the quantity produced are likely making profit in the business while those that pulled out of the business did so probably because they were not making business or because they see another business which could offer them a higher profit. This implies that there was increase in the number of poultry, goatry, fisheries and piggery produced respectively after participation in Fadama III programme

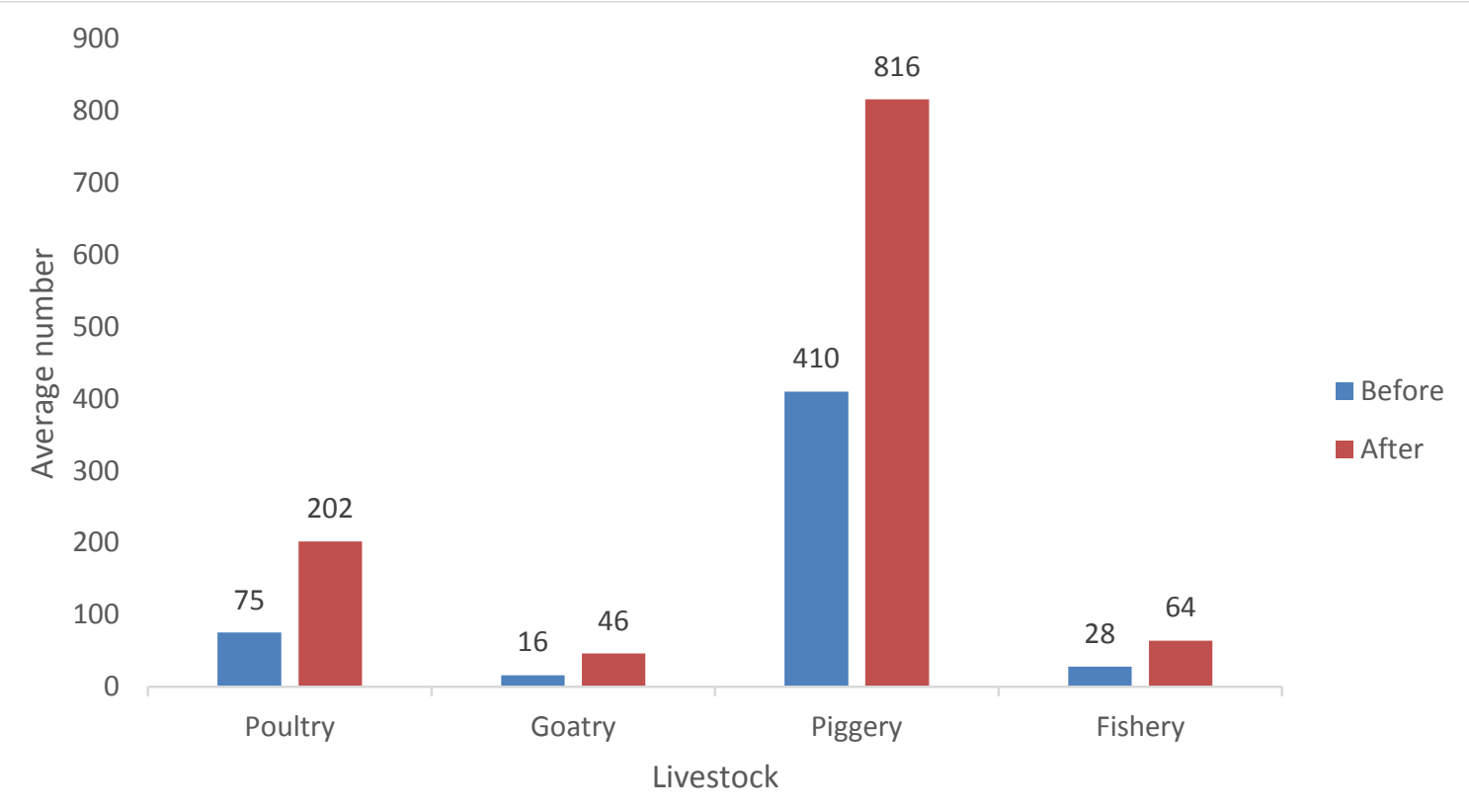

Figure 5: Scale of Livestock production activities Source: Field Survey, 2015 
Creative commons User License: CC BY-NC-ND

Abstracted by: EBSCOhost, Electronic Journals Service (EJS),

Google Scholar, Directory of Open Access Journals (DOAJ),

Journal Seek, Scientific Commons,

Food and Agricultural Organization (FAO), CABI and Scopus
Journal of Agricultural Extension

Vol. 21 (2) June, 2017

ISSN(e): 24086851; ISSN(Print); $1119944 X$

http://journal.aesonnigeria.org

http://www.ajol.info/index.php/jae

Email: editorinchief@aesonnigeria.org

\section{Conclusion and Recommendations}

The scope and scale of beneficiaries farming activities increased significantly after participating in the Fadama programme. The number of farmers involved in the farming activities and the hectares cultivated increased. Also, the number of farmers involved in livestock production and the quantity reared increased after Fadama programme. Based on the performance recorded, the federal government of Nigeria is therefore urged to sustain the Fadama projects after the World Bank withdraws from the programme funding. This will go a long way in improving agriculture.

\section{Reference}

Akinola, M. O. (2003). The performance of fadama users' association under the national fadama development project phase One, Nigeria. A PhD Thesis, Ahmadu Bello Univerty, Zaria, pp. 3-73.

Balogun, O.L and S.A Yusuf (2011). Effects of social capital on welfare of rural Households in south-west states, Nigeria; Journal of Agriculture and social sciences 7: 41-48.

Chabeuf, N., Toledano, J., Bouarfa, Y., Neighbor, H. (2004). Benin: Faster and less costly community development. In William, R. and Gary, A. (Editors) DemandDriven approaches to agriculture extension: Case studies of international initiatives. Agriculture and rural development discussion paper 10. Washington DC, the World Bank: 7-9.

Ekpo, A. H. and Umoh, O. J. (2012). An overview of the Nigerian economic growth and development. Nigeria Daily News online. www.onlinenigeria.com.

Girei, A.A., N. D. Saingbe, M. A. Bitrus, and I. H. Bassey. (2017). Revealing the Impact of Fadama III Project on the Income Level of Beneficiary Farmers in Plateau State, Nigeria. European Journal of Academic Essays 4(2): 26-38,

Koyenikan M. J. and V. E. Ikharea (2014). Participation of Women in the Third National Fadama Development Programme in Edo State, Nigeria. Journal of Agricultural Extension, 18 (2): 133-143.

Makumbe, J. (1996). Participatory Development: The Case of Zimbabwe, Harare. University of Zimbabwe Publications.

Mikkelsen, B. (1995). Methods for development work and research: A guide for practitioners, New Delhi, Sage.

National Bureau of Statistics (2015). Report on the contribution of Agriculture to the Nigeria GDP. Abuja, Nigeria.

Ogbonna, M. O. and Nwaobiala, C. U. (2014). Effect of Fadama III Project On Rural Farm Women Production In Gombe State, Nigeria. Nigerian Journal of Agriculture, Food and Environment. 10(1):13-18.

Oriola, E. O. (2009). A framework for food security and poverty reduction in Nigeria. European Journal of Social Sciences, 8(1).

Osondu C. K., ljioma J. C., Udah S. C., Emerole C. O. (2015). Impact of National Fadama III Development Project in Alleviating Poverty of Food Crop Farmers in Abia State, Nigeria. American Journal of Business, Economics and Management, 3(4): 225-233.

Rosegrant M. W., et al. (2009). Looking into the future for agriculture and AKST (Agricultural Knowledge Science and Technology). In Agriculture at a 
Creative commons User License: CC BY-NC-ND

Abstracted by: EBSCOhost, Electronic Journals Service (EJS),

Google Scholar, Directory of Open Access Journals (DOAJ),

Journal Seek, Scientific Commons,

Food and Agricultural Organization (FAO), CABI and Scopus
Journal of Agricultural Extension

Vol. 21 (2) June, 2017

ISSN(e): 24086851; ISSN(Print); 1119944X

http://journal.aesonnigeria.org

http://www.ajol.info/index.php/jae

crossroads (eds. Mclntyre B. D., Herren H. R., Wakhungu J., Watson R. T.), Washington, DC: Island Press. pp. 307-376. 